\title{
EFFECTS OF URBAN RENEWAL ON RESIDENTIAL PROPERTY VALUES IN TWO NEIGHBOURHOODS OF AKURE, NIGERIA
}

\author{
${ }^{1}$ Bello V. A. and ${ }^{2}$ Nwosu A. E. \\ ${ }^{1}$ Department of Estate Management, Federal University of Technology Akure, Nigeria \\ Email: vicbellofuta@yahoo.com. \\ ${ }^{2}$ Department of Estate Management, Federal Polytechnic Ede, Nigeria \\ Email: nwosuaku@yahoo.com
}

\begin{abstract}
The study was carried out to examine Urban Renewal exercise and its effect on residential property values in Oke-Aro and Odopetu neighbourhoods in Akure, A structured questionnaire was administered on selected residents in the two neighbourhoods (Oke-Aro and Odopetu) using the Systematic Random Sampling Technique. Five hundred and sixty eight (568) questionnaires were administered, out of which four hundred and forty eight (448) were retrieved. The retrieved questionnaires were analyzed using Multiple Linear Regression Technique. The result showed an increase in rental value of residential properties due to upgrading of urban infrastructures in the two neighbourhoods. It is recommended that the state government should embark on comprehensive rehabilitation/upgrading of infrastructures instead of concentrating on road network and drainages only in the neighbourhoods.
\end{abstract}

Key words: Urban Renewal, Residential Property and Values.

\section{Introduction}

Nigeria has been experiencing an accelerated shift of her population from rural to urban areas. This rapid rate of urbanization has engendered several challenges and problems similar to situations in other parts of the world. Mabogunje (2002) noted that cities in Nigeria are typified by substandard and inadequate housing, slums, and lack of infrastructure, transportation problem, low productivity, poverty, crime and juvenile delinquency. These problems become more peculiar in the core areas of the developing countries especially Nigeria where policy for physical development and development control are merely on paper without implementation (Omole 2000). The situation in Akure is not different, with burgeoning and expanding cities confronted with colossal environmental problems of matching the provision of urban infrastructural facilities and services with their levels of demand. When a city is experiencing environmental problems, the city could be said to be decayed (Mabogunje, 1968; Okoye, 1979 and Abumere, 1985).

This prevailing urban situation calls for an urgent action to suppress the tide of the decay which could lead to decline in property values (Diya, 1988). The usual approach to achieve this is urban renewal exercise. Urban renewal according to Mabogunje (1968) is viewed as a deliberate effort to change the urban environment through planned, large scale adjustment of the existing city areas to the present and future requirement for urban living and working. Urban renewal can be done through redevelopment/total clearance, rehabilitation/upgrading and gentrification. Redevelopment/total clearance involves demolition of existing slums. This approach can be employed when the level of decay is high (Omole, 2000 and Mukhija, 2002). Rehabilitation/upgrading is a more economical and acceptable urban renewal approach used in deteriorating housing environments as well as conservation of relatively sound neighbourhoods (Adeniji, 1987 and Egunjobi, 1987). Another important programme according to Agbola (2005) is gentrification whereby old houses are converted from their previous use to new uses. When urban renewal is carried out, it changes the urban environment and makes the living and working condition better for the inhabitant as well as improving the value of properties within the affected neighbourhood. 
This study therefore, intends to examine the urban renewal approach used in Oke-Aro and Odopetu in Akure and its resultant effects on landed properties in these neighbourhoods. The study is concentrated on Oke - Aro and Odepetu neighbourhoods because they are among the oldest residential core areas of the city, which also benefited from the World Bank Urban Development Project to carry out renewal exercise (Ondo state planning report 2006). The remainder of the paper is structured as follows. The next section consists of a review of existing literature on urban renewal and property values. The review is followed by a discussion of the research method employed with the results presented and analyzed. The paper concluded with a summary of findings, recommendation and conclusion.

\section{The Study Area}

Akure is a traditional city and like other Yoruba towns in the country, it existed long before the advent of the British colonial rule in the country. The city is located within Ondo State in the south western part of Nigeria. It lies approximately on latitude $7^{0} 15^{1}$ North of the Equator and longitude $5^{0} 15^{1}$ East of the Greenwich meridian. It is bounded in the North by Ekiti and Kogi State, in the East by Edo state, in the West by Oyo and Ogun State and in the South by Atlantic oceans. Akure is a medium-sized urban centre and became the provincial headquarter of Ondo province in 1939 and the capital city of Ondo State and a local government headquarters in 1976.

The city's morphology has changed over time to assume its present status with its attendant land problems, as experienced in similar medium sized urban centres in Nigeria. The increased relative political influence of Akure as a State capital since 1976 has greatly promoted its rapid growth and increased socio-economic activities resulting in its spatial expansion from an area of about 16 squares kilometres in 1980 to about 30 square kilometres in 2000 (M. W \& H 2000). The population of the city grew from 38,852 in 1952 to 71,106 in 1963 . The 1991 national population census however, puts the population of Akure at 239,139 and its estimated population in 1996 was 269,207 (National Population Commission, 1996). Its estimated population in 2006 was 353,211 with male 175495 and female 177,716 (National Population Commission 2006). At present using a growth rate of 3 percent, the city is estimated to have over 380,000 people (Aribigbola 2008).

Akure city is comprised of so many communities of which Oke - Aro and Odopetu are part of. Oke - Aro and Odopetu have a population of 114,083 (Oke Aro 57,743 and Odopetu $54,730)$ with area coverage of 430 hectares. Oke - Aro is bounded in the North by Arakale Road, in the East by Hospital Road, in the West by Iworokogbasa Road and in the South by Fadaka lane. Odopetu community is bounded in the North by Arakale Road, in the East by Hospital Road, in the West by Irowo Street and in the South by Hospital road (Ondo State Planning Report 2006). Presently there has been an upgrading of infrastructural facilities in the two neighbourhoods. 


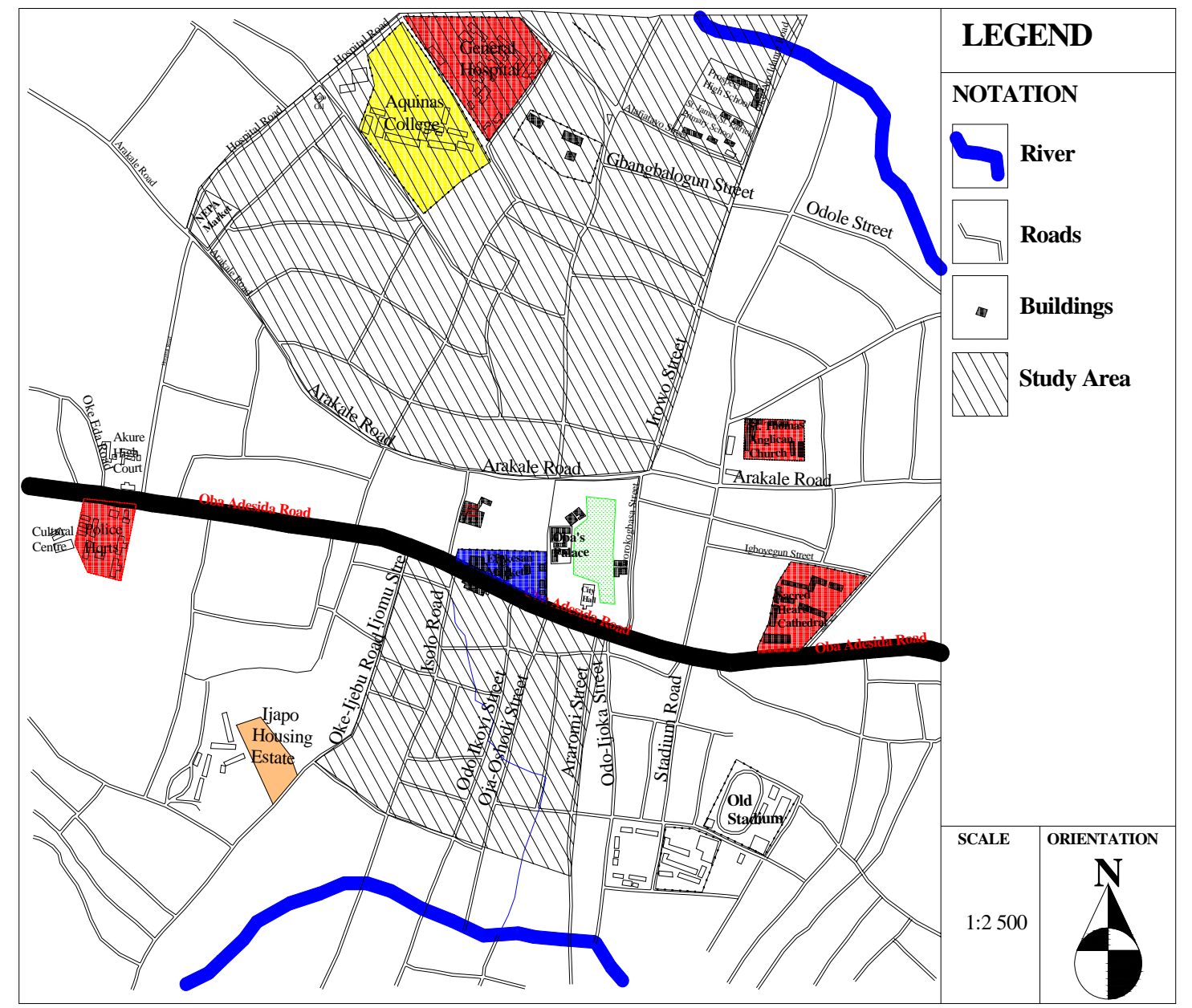

Fig. 1:Street Guide Map of Akure Showing the Study Area Source: Adapted from Ondo State Planning Report, 2006

\section{Urban Renewal and Residential Property Values in Akure}

Urban renewal is a deliberate effort to change the urban environment through planned, large scale adjustment of existing city areas to present future requirements for urban living and working (Mabogunje, 1968). Egunjobi (1987) sees it as an inescapable response to the decaying nature of ageing cities. Agbola (1985, 1987, and 1997) studies reveals urban renewal as "a relatively comprehensive community redevelopment programme through which a particular city seeks to refashion and rebuild the physical structures of a particular segment of the city in order to enable it cope with the many problems confronting it". The views of the different authors are not at variance with one another. What is central to them is the fact that rather than being an end in itself, urban renewal is a process of correcting certain anomalies of cities towards achieving a desirable and environmental socio-economic end which have the tendency of enhancing the values of properties in the vicinity.

Yau et al (2006) carried out an empirical study on the neighbourhood effect of refurbishment and the result showed that urban renewal brought a significant increase in the price of properties in Hong Kong. BSP Writers (2004) also, reported an increase of HK\$1,000 per $\mathrm{ft}^{2}$ in property value after the comprehensive refurbishment of a large residential estate in Hong Kong. Also, Chau et al, (2003) used the hedonic price analysis and found that refurbishment brought about a nine percent increase in property prices which far exceeded the cost of refurbishment. Therefore, it is reasonable to conjecture that the increases in property values in BSP Writers (2004) and Chau et al, (2003) are to a certain extent attributed to two 
forces: the improvement in the subject buildings and the improvement in other buildings of the same estate.

Greene (2003) reported that during the urban renewal programmes carried out in Santo Damingo in the 1980s; housing markets were "dollarized," putting them out of reach of most wage earners. The price of urban land rose and the landholding structure tended to become more concentrated. This situation was exacerbated by lack of eviction protections and irregularities in compensation for displaced families. The author further noted that a move out of a slum room into non-slum accommodation involves a tripling of rental expenditure. The study also reveals that after the upgrading in Kisumu spurred by the Olympics, the price of apartments soared by $20.4 \%$ in the first eight months of 1988 and land prices rose by $27 \%$ in 1988, the steepest rise since 1978.

In the case of Manyatta slum, Huchzermeyer (2006) showed that immediately after the improvement of the urban upgrading project, the price of land shot up by more than $500 \%$. Mukhijia (2000) in his study noted that increase in property values was in expectation of the more valuable housing that was as a result of the upgrading programme. Potentially high property values not only open-up the possibility of cross-subsidy, they also suggest options that are typically not considered by policy-makers in upgrading. Also, Mukhijia (2002) studied slum Upgrading and Property values and the result revealed that property values increased significantly as a result of upgrading exercise.

In the study areas (Oke - Aro and Odopetu) however, urban renewal exercise was adopted. The renewal exercise was necessary because the communities were among the oldest in the residential core areas of Akure, where slum has become so prevalent ((Ondo State Planning Report 2006).

\section{Research Methodology}

Data used in the study were collected using a structured questionnaire administered to selected residents in the two neighbourhoods (Oke-Aro and Odopetu). Systematic random sampling technique was used in the administration of questionnaires in which the first house was randomly selected and every $3^{\text {rd }}$ house was systematically selected. A total number of five hundred and sixty eight (568) questionnaires were administered out of which four hundred and forty eight (448) were retrieved representing $79 \%$ response rate. The retrieved questionnaires were analyzed using the Multiple Linear Regression Analysis to test the relationship between market rents (dependent variable) for residential properties and various independent variables (Table 1). The regression model used for the study is stated as:

MKTRENT $=b_{0}+b_{1}$ ELEC $+b_{2}$ WATR $+b_{3}$ ROADNWK $+b_{4}$ DRAINF $+b_{5}$ WASTDP + $\mathrm{b}_{6} \mathrm{PARKSP}+\mathrm{b}_{7}$ RECREATF $+\mathrm{b}_{8}$ STREETLT $+\mathrm{b}_{9} \mathrm{SECUTY}+\mathrm{b}_{10} \mathrm{HOSP}+$ 
Table 1: Variable Codes and Description

\begin{tabular}{|l|l|l|}
\hline \multicolumn{1}{|c|}{ VARIABLES CODES } & \multicolumn{1}{c|}{ DESCRIPTION } & MEASUREMENT \\
\hline MKTRENT & Market rent for the Property & Naira \\
\hline ELEC & Electricity Supply & $\begin{array}{l}\text { Available }=1, \\
\text { Not available }=0\end{array}$ \\
\hline WATR & Water Supply & $\begin{array}{l}\text { Available }=1, \\
\text { Not available }=0\end{array}$ \\
\hline ROADNWK & Road Network & $\begin{array}{l}\text { Good }=1, \text { Not Good }=0 \\
\text { Drailable }=1, \\
\text { Not available }=0\end{array}$ \\
\hline WASTD & Drainage System & $\begin{array}{l}\text { Available }=1, \\
\text { Not available }=0\end{array}$ \\
\hline PARKSP & Waste Dump & $\begin{array}{l}\text { Available }=1, \\
\text { Not available }=0\end{array}$ \\
\hline RECREATF & Parking Space & $\begin{array}{l}\text { Available }=1, \\
\text { Not available }=0\end{array}$ \\
\hline STREETLT & Recreational Facility & $\begin{array}{l}\text { Available }=1, \\
\text { Not available }=0\end{array}$ \\
\hline SECURITYP & Street Light & $\begin{array}{c}\text { Available }=1, \\
\text { Not available }=0\end{array}$ \\
\hline HOSP & Security of Properties & Number \\
\hline SCHL & Hospital & Number \\
\hline
\end{tabular}

Source: Author, 2011

Data Analysis and Discussion of Results

Evaluation of the Urban Renewal Approaches adopted in the neighbourhoods

In this section, a five (5) - point Likert Scale technique was used to evaluate the urban renewal approaches applied in the two neighbourhoods in Akure. These are shown in Tables 2 and 3.

Table 2: Urban Renewal Approach carried out in Oke - Aro neighbourhood of Akure

\begin{tabular}{|l|c|c|c|c|c|c|l|}
\hline Approach & $\begin{array}{l}\text { Strongly } \\
\text { Disagree } \\
(1)\end{array}$ & Disagree & Undecided & Agree & $\begin{array}{l}\text { Strongly } \\
\text { Agree } \\
(5)\end{array}$ & $\begin{array}{l}\text { Mean } \\
\text { Rating } \\
\text { Value }\end{array}$ & Rank \\
\hline $\begin{array}{l}\text { Redevelopment/ } \\
\text { Total Clearance }\end{array}$ & 99 & 63 & 31 & 23 & 15 & 2.10 & 5 \\
\hline $\begin{array}{l}\text { Rehabilitation/ } \\
\text { Upgrading }\end{array}$ & 8 & 9 & 24 & 69 & 121 & 4.24 & 1 \\
\hline Gentrification & 66 & 49 & 33 & 45 & 38 & 2.74 & 4 \\
\hline Conservation & 9 & 24 & 54 & 83 & 61 & 3.71 & 2 \\
\hline $\begin{array}{l}\text { Economic } \\
\text { Revitalization }\end{array}$ & 18 & 19 & 36 & 101 & 57 & 3.69 & 3 \\
\hline
\end{tabular}

Source: Field Data, 2011 
Table 3: Urban Renewal Approach carried out in Odopetu neighbourhood of Akure

\begin{tabular}{|l|c|c|c|c|c|l|l|}
\hline Approach & $\begin{array}{l}\text { Strongly } \\
\text { Disagree } \\
(1)\end{array}$ & Disagree & Undecided & Agree & $\begin{array}{l}\text { Strongly } \\
\text { Agree } \\
(5)\end{array}$ & $\begin{array}{l}\text { Mean } \\
\text { Rating } \\
\text { Value }\end{array}$ & Rank \\
\hline $\begin{array}{l}\text { Redevelopment/ } \\
\text { Total Clearance }\end{array}$ & 106 & 40 & 38 & 24 & 9 & 2.03 & 5 \\
\hline $\begin{array}{l}\text { Rehabilitation/ } \\
\text { Upgrading }\end{array}$ & 4 & 6 & 22 & 62 & 123 & 4.35 & 1 \\
\hline Gentrification & 56 & 48 & 35 & 44 & 34 & 2.78 & 4 \\
\hline Conservation & 5 & 19 & 38 & 95 & 60 & 3.86 & 2 \\
\hline $\begin{array}{l}\text { Economic } \\
\text { Revitalization }\end{array}$ & 2 & 31 & 46 & 82 & 56 & 3.73 & 3 \\
\hline
\end{tabular}

Source: Field Data, 2011

Tables 2 and 3 show the occupants in the communities (Oke-Aro and Odopetu) to have a mean score of 4.24, 4.35 respectively for Rehabilitation/Upgrading. This is in conformity with the findings of Omole (2000) and Egunjobi (1987) that Rehabilitation/Upgrading is the best option when renewing an area that is deteriorated. Conservation approach however, ranked second with a mean score of 3.71 and 3.86 for Oke - Aro and Odopetu respectively.

Effect of Urban Renewal on Residential Property Values in Oke - Aro and Odopetu

The effect of Urban Renewal on property values in the neighbourhoods was analysed using the Time Series and Multiple Linear Regression Analysis.

Time Series Analysis for Oke - Aro and Odopetu

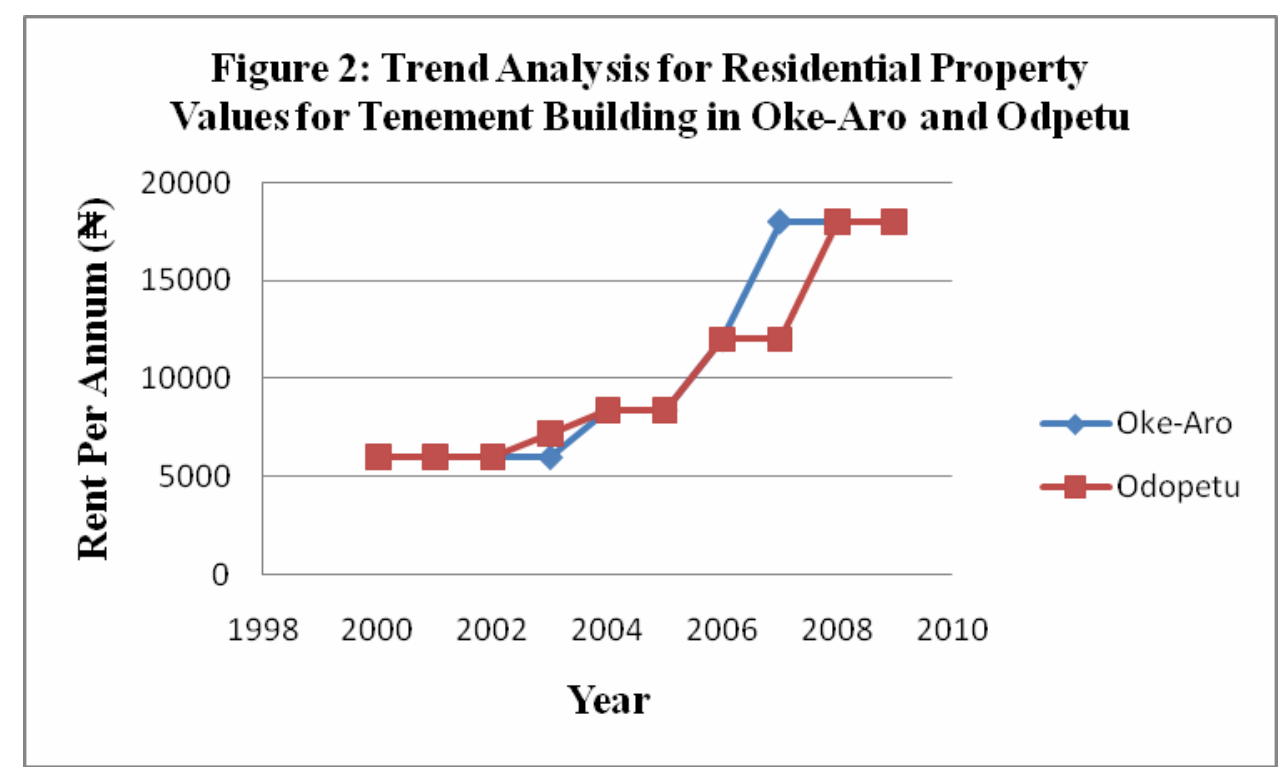

Source: Field Survey, 2011 


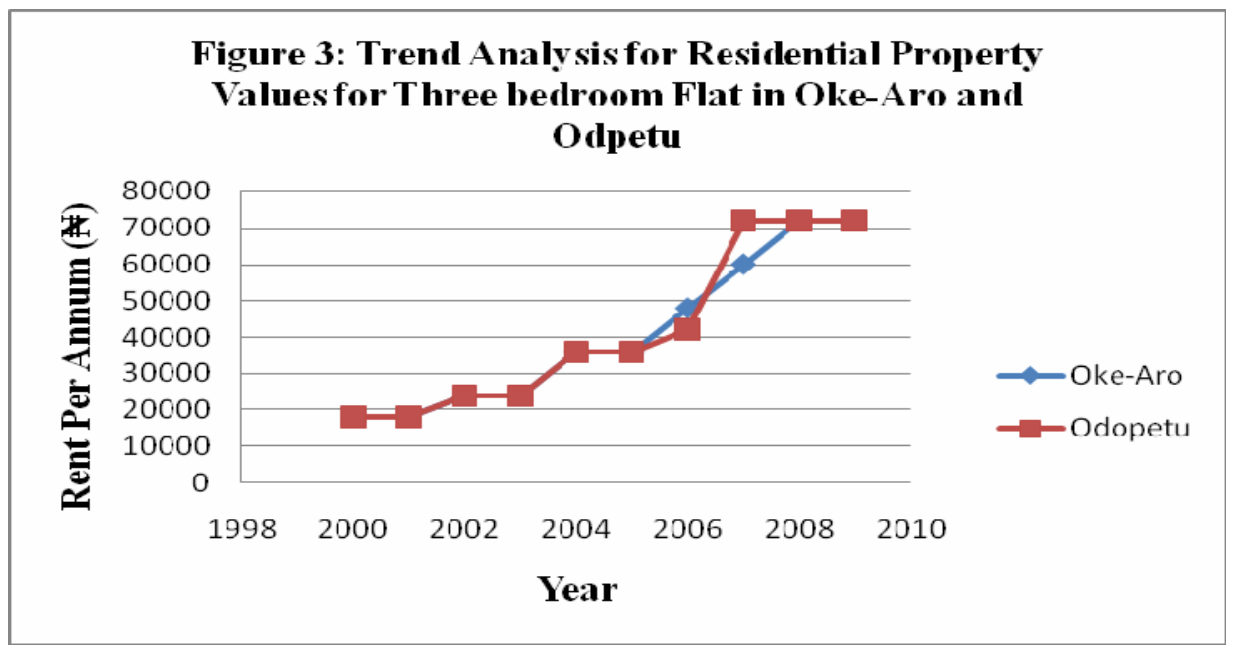

\section{Source: Field Survey, 2011}

Figures 2 and 3 show the rental values of residential properties in Oke - Aro and Odopetu neighbourhoods for both tenement and three bedrooms flat. In figure 2, the rent passing on the tenement buildings in the neighbourhoods (Oke - Aro and Odopetu) were relatively stable at N6,000 per annum from year 2000 to 2002. For 3 - bedroom flat the two neighbourhoods (Oke - Aro and Odopetu) has a stable rent of $\mathrm{N18,000}$ per annum in year 2000 and 2001 as shown in figure 3. Figure 2 and 3 also, reveals a slight increase in rental value for tenement buildings and 3-bedroom flat accommodation in 2004 for both Oke - Aro and Odopetu neighbourhoods. In 2004 the rent increased from the stable rent of $N 6,000$ per annum to $N 8,400$ per annum for tenement type of accommodation while for 3- bedroom flats the rent was increased to N36,000 per annum. The reason could be from the normal rent increase by the landlords. Also, Fig 2 and 3 shows a contrasting sharp rise in rental value for the residential properties between the periods of $2007-2009$. For instance, the rental values for tenement properties rose to $N 18,000$ naira per annum in 2007 and was stable to 2009 in the two neighbourhoods while for 3bedroom flats it was $\mathbf{N 6 0 , 0 0 0}$ per annum in 2007 and rose to $N 72,000$ per annum in 2009 for Oke - Aro. In addition in Odopetu the rent rose to $N 72,000$ in 2007 and was stable to 2009. This is expected as the neighbourhoods witnessed infrastructural development and urban renewal through rehabilitation/upgrading by the World Bank Project undertaken by the State Government.

\section{Regression Analysis in Oke - Aro}

The results of the regression analysis showing the effect of urban renewal exercise undertaken in Oke - Aro are detailed in Tables 4, 5, 6 and 7.

Table 4: Model Summary in Oke - Aro

\begin{tabular}{|l|l|l|l|l|}
\hline Model & R & R - Square & Adjusted R Square & Std. Error of the Estimate \\
\hline & $.934^{\mathrm{a}}$ & .873 & .886 & 7305.670 \\
\hline
\end{tabular}

\section{Source: Analysis of Field Data, 2011}

Table 5: Analysis of Variance (ANOVA) in Oke - Aro

\begin{tabular}{|l|l|l|l|l|l|}
\hline Model & Sum of Squares & Df & Mean Square & F & Sig. \\
\hline Regression & $8.0 \mathrm{E}+010$ & 11 & 7279657352 & 136.393 & $.000^{\mathrm{a}}$ \\
Residual & $1.2 \mathrm{E}+010$ & 219 & 53372809.68 & & \\
Total & $9.2 \mathrm{E}+010$ & 230 & & & \\
\hline
\end{tabular}

\section{Source: Analysis of Field Data, 2011}


Table 4 shows the summary of results of the regression model. The overall model fits well as indicated by $\mathrm{R}^{2}(0.873)$. This implies that $87.3 \%$ of the sample variation of rental value of properties in Oke - Aro is explained by the independent variables. The computed F- statistics (136.393) shown in Table 5 falls within the rejection region signifying that at least one of the model coefficient is non - zero.

Table 6: Regression Coefficients in Oke - Aro

\begin{tabular}{|c|c|c|c|c|c|}
\hline \multirow[t]{2}{*}{ Model } & \multicolumn{2}{|c|}{$\begin{array}{l}\text { Unstandardized } \\
\text { Coefficients }\end{array}$} & \multirow{2}{*}{$\begin{array}{l}\text { Stanndardized } \\
\text { Coefficients } \\
\text { Beta }\end{array}$} & \multirow[t]{2}{*}{ T- test } & \multirow[t]{2}{*}{ Sig. } \\
\hline & $\mathrm{B}$ & Std.Error & & & \\
\hline (Constant) & 102479.1 & 3620.902 & & 28.302 & .000 \\
\hline ELEC & -60.958 & 2282.275 & -.003 & -.027 & .979 \\
\hline WATR & -6140.860 & 1750.878 & -.348 & -3.507 & $.001^{*}$ \\
\hline ROADNWK & -6213.333 & 2198.596 & -.312 & -2.826 & $.005^{*}$ \\
\hline DRAINF & -9922.029 & 1624.768 & -.484 & -6.107 & $.000^{*}$ \\
\hline WASTD & -6455.561 & 2161.886 & -.384 & -2.986 & $.003 *$ \\
\hline PARKSP & -8097.996 & 1538.241 & -.527 & -5.264 & $.000 *$ \\
\hline RECREATF & 2954.781 & 1768.262 & -150 & 1.671 & .096 \\
\hline STREETLT & -2700.504 & 1322.799 & -.160 & -2.042 & $.042 *$ \\
\hline SECUTY & 12545.680 & 2646.482 & .699 & 4.741 & $.000^{*}$ \\
\hline HOSP & 4173.554 & 1846.311 & .189 & 2.260 & $.025 *$ \\
\hline $\mathrm{SCHL}$ & 2299.172 & 1557.282 & .133 & 1.476 & .141 \\
\hline
\end{tabular}

Source: Analysis of Field Data, 2011

Significant at 0.05

* Significant

The model for Oke - Aro is shown below

MKTRENT $=102479.1-60.958 E L E C-6140.860$ WATR -6213.333 ROADNWK

- 9922.029DRAINF - 6455.561WASTD - 8097.996PARKSP + 2954.781RECREATF

-2700.504 STREETLT + 1254.680SECUTY + 4173.554HOSP + 2299.172SCHL

Table 6 shows that eight of the variables used in the analysis are significant. The variables include, Water (WATR), road network (ROADNWK), drainage (DRAINF), waste disposal (WASTD), parking space (PARKSP), street light (STREETLT), security (SECUTY) and hospital (HOSP). These variables are significant probably because the infrastructures were upgraded during the urban renewal exercise and are still functioning. However, the relationship between electricity (ELEC), recreational facility (RECREATF) and school (SCHL) with market rent of residential properties in the neighbourhood are not significant. One may wonder why electricity is not significant. This is not unconnected with the epileptic power supply (electricity) being experienced in the country. As a result of this, most households have resulted into owning at least a generating set. The other variables (RECREATF and SCHL) that are not significant may be because the facilities are commonly shared by the community and tenants do not attach much importance to them when paying rents. 
Table 7: Zero-order, Partial and Part correlation Coefficients in Oke - Aro

\begin{tabular}{|l|l|l|l|}
\hline \multirow{2}{*}{ Model } & \multicolumn{3}{|c|}{ Correlations } \\
\cline { 2 - 4 } & Zero-order & Partial & Part \\
\hline ELEC & -.804 & -.002 & -.001 \\
\hline WATR & -.883 & -.231 & -.085 \\
\hline ROADNWK & -.837 & -.188 & -.068 \\
\hline DRAINF & -.878 & -.381 & -.147 \\
\hline WASTD & -.894 & -.198 & -.072 \\
\hline PARKSP & -.717 & -.335 & -.127 \\
\hline RECREATF & -.646 & -.112 & .040 \\
\hline STREETLT & -.622 & -.137 & -.049 \\
\hline SECUTY & -.841 & .305 & .114 \\
\hline HOSP & -.789 & .151 & .055 \\
\hline SCHL & -.838 & .099 & .036 \\
\hline SOUTC: AnalyS & & &
\end{tabular}

Source: Analysis of Surveyed Data, 2011

Significant at 0.05

* Significant

The relative importance of the variables can be seen from the Zero - order, Part and Partial correlations between property values and the independent variables (Table 7). The Pearson coefficients of correlation indicate a relatively stronger linear relationship between rental values and all the independent variables in Oke - Aro.

\section{Regression Analysis in Odopetu}

Table 8: Model Summary in Odopetu.

\begin{tabular}{|l|l|l|l|l|}
\hline Model & $\mathrm{R}$ & $\mathrm{R}$ Square & $\begin{array}{l}\text { Adjusted R } \\
\text { Square }\end{array}$ & $\begin{array}{l}\text { Std. Error of } \\
\text { the Estimate }\end{array}$ \\
\hline & $.905^{\mathrm{a}}$ & .819 & .809 & 8161.828 \\
\hline
\end{tabular}

\section{Source: Field Survey 2011}

Table 9: Analysis of Variance (ANOVA) in Odopetu

\begin{tabular}{|l|l|l|l|l|l|}
\hline Model & $\begin{array}{l}\text { Sum of } \\
\text { Squares }\end{array}$ & Df & Mean Square & F & Sig. \\
\hline Regression & $6.2 \mathrm{E}+010$ & 11 & 5621070880 & 84.381 & $.000^{\mathrm{a}}$ \\
Residual & $1.4 \mathrm{E}+010$ & 205 & 66615428.31 & & \\
Total & $7.5 \mathrm{E}+010$ & 216 & & & \\
\hline
\end{tabular}

\section{Source: Analysis of Surveyed Data, 2011}

The performance of the model as shown in Tables 8 and 9 is good as indicated by $R^{2}$ statistic (0.819). This implies that $81.9 \%$ of the sample variation in the rental values is attributed to the independent variables. The computed $F$ statistic is 84.341 . Since the value of $F$ statistic falls within the rejection region, the data signifies that at least one of the model coefficients is nonzero. 
Table 10: Regression Coefficients in Odopetu

\begin{tabular}{|c|c|c|c|c|c|}
\hline \multirow[t]{2}{*}{ Model } & \multicolumn{2}{|c|}{$\begin{array}{l}\text { Unstandardized } \\
\text { Coefficients }\end{array}$} & \multirow{2}{*}{$\begin{array}{l}\text { Stanndardized } \\
\text { Coefficients } \\
\text { Beta }\end{array}$} & \multirow[t]{2}{*}{ T- test } & \multirow[t]{2}{*}{ Sig. } \\
\hline & B & Std.Error & & & \\
\hline (Constant) & 95436.648 & 3980.579 & & 23.976 & .000 \\
\hline ELEC & 1983.505 & 1703.053 & .098 & 1.165 & .246 \\
\hline WATR & -8317.558 & 2051.714 & -.502 & -4.054 & $.000^{*}$ \\
\hline ROADNWK & -7130.770 & 2841.017 & -.431 & -2.510 & $.013^{*}$ \\
\hline DRAINF & -5951.920 & 2973.930 & -.324 & -2.001 & $.047^{*}$ \\
\hline WASTD & 4582.904 & 1979.819 & .295 & 2.315 & $.022 *$ \\
\hline PARKSP & -1746.702 & 2255.780 & -.088 & -.774 & .440 \\
\hline RECREATF & 73.709 & 2217.540 & .003 & .033 & .974 \\
\hline STREETLT & -3001.341 & 2668.919 & -.166 & -1.125 & .262 \\
\hline SECUTY & 1234.252 & 1723.171 & .072 & .716 & .475 \\
\hline HOSP & -766.624 & 2030.800 & -.035 & -.377 & .706 \\
\hline $\mathrm{SCHL}$ & 2256.791 & 2626.994 & .129 & .859 & .391 \\
\hline
\end{tabular}

Source: Analysis of Surveyed Data, 2011

Significant at 0.05

* Significant

The model for Odopetu is shown below.
MKTRENT $=95436.648+1983.505 E L E C-8317.558$ WATR - 7130.770ROADNWK -5951.920DRAINF + 4582.904WASTD - 1746.702PARKSP + 73.709RECREATF -3001.341 STREETLT + 1234.252SECUTY - 766.624HOSP + 2256.791

In Table 10, four variables are significant. The variables are water (WATR), road network (ROADNWK), waste disposal (WASTPD) and drainage (DRAINF). This implies that the variables have significant impact on the value of residential properties in the study area. This may be because they are still functioning and the government is making effort to maintain and upgrade them. The relationship between rental values of residential property and variables such as electricity (ELEC), street light (STREETLT), parking space (PARKSP), recreational facility (RECREAF) security (SECUTY), hospital (HOSP) and school (SCHL) is negative. This is expected as the variables are facilities usually provided by government and may be inadequate where they exist.

Table 11: Zero-order, Partial and Part correlation Coefficients

\begin{tabular}{|l|l|l|l|}
\hline \multirow{2}{*}{ Model } & \multicolumn{3}{|c|}{ Correlations } \\
\cline { 2 - 4 } & Zero-order & Partial & Part \\
\hline ELEC & -.790 & .081 & .035 \\
\hline WATR & -.869 & -.272 & -.120 \\
\hline ROADNWK & -.862 & -.173 & -.075 \\
\hline DRAINF & -.833 & -.078 & -.033 \\
\hline WASTD & -.833 & .160 & .069 \\
\hline PARKSP & -.647 & -.058 & -.023 \\
\hline RECREATF & -.600 & .002 & .001 \\
\hline STREETLT & -.859 & -.138 & -.059 \\
\hline SECUTY & -.807 & .050 & .021 \\
\hline HOSP & -.840 & -.026 & -.011 \\
\hline SCHL & -.840 & .060 & .026 \\
\hline
\end{tabular}

Source: Analysis of Surveyed Data, 2011 
Table 11 shows the Zero order, Partial and Part Correlation. The Pearson coefficient of correlation indicates a strong linear relationship between the independent variables and rental values in Odopetu.

\section{Summary of Findings, Policy Implication and Conclusion}

The Urban Renewal exercise undertaken in the neighbourhoods (Oke - Aro and Odopetu) was the Rehabilitation/Upgrading of infrastructures. These two neighbourhoods benefited from the World Bank Urban Development Project to carry out the renewal exercise (Ondo State Planning Report 2006). The renewal exercise however increased the value of residential properties in the areas (Oke - Aro and Odopetu).

Although the Rehabilitation/Upgrading exercise carried out in the neighbourhoods is in the right direction, effort should be made on the part of the state government to carry out complete Rehabilitation/Upgrading of all the infrastructures. In addition, government should develop the habit of maintenance culture were infrastructures are prevented from decaying completely. The issue of electricity supply is very important in any nation to develop; government at all levels should find a lasting solution to the epileptic power supply in the neighbourhoods and Nigeria as a whole. Also, residents should be enlightened on the importance of maintenance culture so as to conserve the facilities already put in place. There should also, be a strong and effective method of enforcing building regulatory standards to make sure that buildings that are not in conformity with regulatory standard for living is demolished. This action if adhered to will create an environment conducive for everyone to work and live in.

\section{References}

Abumere, S. I. (1985). The Nigerian Urban Environment and the Problem of Slums. Department of Geography, University of Ibadan.

Adeniji, K. (1987). Urban Renewal case studies from Britan, in Adepoju,G., Olokesusi, F. and Egunjobi, L. (eds.) Urban Renewal in Nigeria, NISER Ibadan.

Agbola, T. (1985). Property Taxation, Paper Presented at a Seminar on Local Sources of Finance for Local Governments, ASCON, Badagry, February 1985.

Agbola, T. (1987). Urban Renewal, A case study of Lagos Metropolitan Area, in Adepoju, G., Olokesusi, F. and Egunjobi, L. (eds.) Urban Renewal in Nigeria, NISER/CERP, Ibadan 88100.

Agbola, T. (1997). Sustainable Cities programme: the case of sustainable Ibadan project (SIP) and lessons from abroad in Adeniji et al (eds.) Sustainable physical development in Nigeria.

Agbola, T. (2005). Urbanization, Physical Planning and Urban Development in West Africa, Proceedings of CAP West African Regions, World Planet Congress Agenda Settings Workshop held between November $14^{\text {th }}$ and $15^{\text {th }} 2005$.

Aribigbola, A. (2008). Housing Policy Formulation in Developing Countries: Evidence of Programme Implementation for Akure, Ondo State, Nigeria. Journal of Humanities and Ecology, 23 (2), 125 - 134.

BSP Writers (2004). The reward of repair and renovation; Building Services Professional. December 2004, 24-26.

Chau, K.W; Leung, A.Y; Yiu, C.Y and Wong, S.K (2003). Estimating the Value Enhancement Effect of Refurbishment facilities 21(1/2), 13-19

Diya, (1988). Determinants of Residential Property Values. Newsletter, 1 (4).

Egunjobi, L. (1987). Urban Renewal issues, policies, strategies and planning in England in

Adepoju, G. Olokesusi, F. and Egunjobi, L. (eds.) Urban Renewal in Nigeria, NISER Ibadan.

Greene, S. (2003). Staged Cities Mega-events, Slum Clearance and Global Capital.

Huchzermeyer, M. (2006). Slum Upgrading Initiatives in Kenya within the Basic Service and wider Housing Market; A housing right Concern. Discussion Paper No (1) Kenya Housing 
Rights Projects, COHRE African Programme Centre on Housing Right and Eviction, Geneva.

Mabogunje, C. (1968). Urbanization in Nigeria. University of London Press.

Mabogunje, A. (2002). Re-constructing the Nigeria City; The New Policy on Urban Development and Housing, Paper Presented at a National Conference on the City in Nigeria, Ile-Ife

Ministry of Works and Housing, Akure Ondo State, Nigeria. Akure Master Plan $1980-2000$.

Mukhija, V. (2000). Squatters as Developers? Mumbai's Slum Dwellers as Equity Partners in Redevelopment. Ph.D. Dissertation, Massachusetts Institute of Technology, Cambridge, MA.

Mukhija, V. (2002). An Analytical Framework for Urban Upgrading: Property Right, Property Values and Physical Attributes. Habitat International 553-570.

NPC (1996). National Population Commission. Census 91, Final Results Ondo State.

Okoye, T. (1979). Urban Planning in Nigeria and the Problem of Slums in the Third World Planning Review journal, ( 1) 71-85.

Omole, F.K. (2000). Planning Theories and the Planners. Peace Ground Publication, Ilesha, Nigeria.

Ondo State Planning Report, (2006). A Report Submitted to the Millennium Development Goals.

Yau, Y, Wong .S, Cheung. A.C, Chau. K.W and Ho. D.C (2006). An Empirical Study on the Neighbourhood Effect of Refurbishment. International Journal of Housing Market and Analysis, 1 (1), 19 - 32. 